\title{
Roles for Azorhizobial Nod Factors and Surface Polysaccharides in Intercellular Invasion and Nodule Penetration, Respectively
}

\author{
Wim D’Haeze, ${ }^{1}$ Mengsheng Gao, ${ }^{1}$ Riet De Rycke, ${ }^{1}$ Marc Van Montagu, ${ }^{1}$ Gilbert Engler, ${ }^{2}$ \\ and Marcelle Holsters ${ }^{1}$ \\ ${ }^{1}$ Laboratorium voor Genetica, Departement Genetica, Vlaams Interuniversitair Instituut voor Biotechnologie \\ (VIB), Universiteit Gent, K. L. Ledeganckstraat 35, B-9000 Gent, Belgium; '2aboratoire Associé \\ de I'Institut National de la Recherche Agronomique (France), Universiteit Gent, B-9000 Gent, Belgium \\ Accepted 22 June 1998.
}

In the symbiotic interaction between Azorhizobium caulinodans and Sesbania rostrata root and stem-borne nodules are formed. The bacteria enter the host via intercellular spaces at lateral or adventitious root bases and form infection pockets in outer cortical layers. Infection threads guide the bacteria to nodule primordia where plant cells are invaded. To identify bacterial functions that are required for this infection process, two mutants defective in nodulation were studied; one produced no Nod factors (nodA mutant), the other had altered surface polysaccharides (SPS) and induced the formation of pseudo-nodules. Bacteria were visualized with the help of a nodA-uidA reporter fusion that was functional during nodule development and in bacteroids. In contrast to the SPS mutant, nodA mutants were unable to colonize outer cortical regions. In mixed inoculations with both mutants, functional nodules were formed, the central tissue of which was occupied by the nodA mutant. These observations suggest that SPS play a role in deeper invasion and that Nod factors are necessary for entry. Simultaneous application of purified Nod factors and nodA mutant bacteria restored the formation of outer cortical infection pockets leading to the conclusion that intercellular infection is an active process that is dependent on bacterial Nod factor signaling.

Additional keywords: GUS, LCO.

Bacteria belonging to the genera Rhizobium, Azorhizobium, Bradyrhizobium, Mesorhizobium, and Sinorhizobium are able to establish a symbiotic interaction with leguminous host plants (reviewed by Mylona et al. 1995; Long 1996). Upon an exchange of specific signals between the symbiotic partners, root nodules are formed that contain nitrogen-fixing bacteroids. One of the initial steps of the symbiotic interaction is the recognition of specific flavonoids by a bacterial regulatory NodD protein, leading to the expression of nodulation (nod)

Corresponding author: M. Holsters, Laboratorium voor Genetica, Universiteit Gent, K. L. Ledeganckstraat 35, B-9000 Gent, Belgium; Fax 32-9-2645349; E-mail: mahol@gengenp.rug.ac.be

Wim D'Haeze and Mengsheng Gao have contributed equally to this work. genes (reviewed by Schultze et al. 1994). nod genes encode Nod proteins that cooperate to synthesize and secrete a Nod factor return signal. Nod factors are lipochitooligosaccharides (LCOs) consisting of a tri-, tetra-, or pentameric chitin backbone that is substituted with strain-specific modifications at the reducing and nonreducing end (reviewed by Dénarié et al. 1996; Mergaert et al. 1997b). Nano- to picomolar concentrations of LCOs elicit plant responses in the epidermis, cortex, and pericycle of the root, including membrane depolarizations, root hair formation and deformation, pre-infection thread and nodule primordium formation, and induction of several plant genes (reviewed by Heidstra and Bisseling 1996; Spaink 1996).

The primary infection of the host plant tissues can occur via either intra- or intercellular penetration. The intracellular mode of infection, which takes place via root hairs, has been most widely studied. Bacteria induce root hair tips to curl, become trapped in the curls, and then enter the plant via an ingrowing tubular structure, the infection thread (reviewed by Bauer 1981; Kijne 1992). Bacteria in the tip of the infection thread divide whereas elsewhere they are rather static (Gage et al. 1996). Concomitantly with infection thread formation, cortical cells start to divide, forming nodule primordia. When infection threads reach the nodule primordia, the bacteria are released into the plant cell cytoplasm. The involvement of Nod factors in this root hair infection process has been unambiguously demonstrated. Purified Nod factors in concentrations as low as $10^{-12} \mathrm{M}$ can cause deformation of root hairs present in a small, susceptible zone of the root (Heidstra et al. 1994; Heidstra and Bisseling 1996). Moreover, Nod factors function as keys to the legume door, because they allow rhizobia to penetrate the root via infection threads (Relić et al. 1994). Nodulation signal production-defective mutants of Rhizobium sp. NGR234 and Bradyrhizobium japonicum USDA110 could be complemented to nodulate Vigna unguiculata and Glycine max, respectively, by an exogenous supply of Rhizobium sp. NGR234 Nod factors in a concentration of $10^{-7}$ to $10^{-6} \mathrm{M}$ (Relić et al. 1994).

A distinct mode of entering the plant tissue appears when rhizobia do not use root hairs but invade the plant tissues intercellularly. Often this infection takes place at cracks created at the junctions of lateral roots with the main root (Sprent and de Faria 1988). This intercellular infection is used in the inter- 
action between Azorhizobium caulinodans ORS571 and the tropical legume Sesbania rostrata. In this symbiosis determinate nodules are formed at the bases of lateral roots and stem-located adventitious rootlets. The development of stem-borne nodules has been studied by light and electron microscopy and in situ hybridizations (Tsien et al. 1983; Duhoux 1984; Goormachtig et al. 1997). The stem-located nodulation sites of $S$. rostrata consist of protruding rootlets surrounded by a fissure and an epidermal dome. The adventitious rootlets have a central vascular bundle, cortical cells, and an apical dormant root meristem. Bacteria colonizing the fissure penetrate the outer cortex of the rootlet and form densely populated infection pockets located two to three cell layers beneath the surface. Opposite of these, nodule primordia are formed in the inner cortex. Bacteria reach the nodule primordia via interand intracellular infection threads. Finally, bacteria are released from the infection threads and are internalized inside plant cells.

To identify bacterial functions required for successful invasion of the host, light and electron microscopy were used to investigate the infection behavior of the wild type and nodulation-defective mutants. Two mutant strains were used: one was defective in Nod factor production (strain ORS571-V44;

Table 1. Comparison of Nod factor (NF) synthesis, surface polysaccharides (SPS), and nodulation behavior (NOD) between ORS571, ORS571-X15, and ORS571-V44

\begin{tabular}{lccc}
\hline Strain & NF & SPS & NOD \\
\hline ORS571 & + & + & + \\
ORS571-X15 & $+^{\mathrm{a}}$ & $-{ }^{\mathrm{b}}$ & $-{ }^{\mathrm{c}}$ \\
ORS571-V44 & - & $+^{\mathrm{d}}$ & - \\
\hline
\end{tabular}

${ }^{a}$ Identical NF population as found for the wild-type strain.

${ }^{b}$ Goethals et al. (1994) showed by sodium dodecyl sulfatepolyacrylamide gel electrophoresis (SDS-PAGE) followed by silver staining that the SPS pattern of ORS571-X15 was different from that of the wild-type strain.

${ }^{c}$ ORS571-X15 induces the formation of pseudo-nodules that never develop into mature nodules (Fig. 1C).

${ }^{\mathrm{d}}$ SDS-PAGE followed by silver staining showed the same pattern as for the wild-type strain (data not shown).
Mergaert et al. 1993), the other had altered surface polysaccharides (SPS) (strain ORS571-X15; Goethals et al. 1994). To detect the bacteria in the plant tissues, the uidA reporter gene, encoding the $\beta$-glucuronidase enzyme (GUS; Jefferson 1987), under the control of the nodA promoter region, was introduced into the strains on a stable, wide-host-range plasmid (Van den Eede et al. 1992). The data presented here show that infection of host tissues by A. caulinodans depends on both Nod factor production and surface properties. Nod factors are essential for initial intercellular invasion whereas SPS meet the opposite requirement: they are not important for the initial colonization, but they are essential for deeper invasion of nodule tissues.

\section{RESULTS}

\section{Nodulation-defective mutants.}

The mutant strain ORS571-X15 contains a Tn5 insertion in a dTDP-D-glucose synthase gene involved in the production of deoxy sugars (Goethals et al. 1994; W. D'Haeze and M. Holsters, unpublished data). Sodium dodecyl sulfate-polyacrylamide gel electrophoresis (SDS-PAGE) followed by silver staining showed a very aberrant lipopolysaccharide pattern (Goethals et al. 1994; Table 1). Because the possibility that the Tn5 insertion also affected the synthesis of other SPS could not be excluded, ORS571-X15 is described here as an SPS-changed mutant. This mutant strain induced the formation of small swellings (pseudo-nodules) in the regular nodulation sites of the host plant (Table 1; Fig. 1C). The structure of Nod factors of ORS571-X15 was determined and compared with the wild-type Nod factors, which have been described previously (Mergaert et al. 1997a). A large-scale Nod factor preparation was carried out and the vaccenoylated (C18:1) and palmitoylated (C16:0) LCOs were separated from the stearoylated (C18:0) LCOs. A fast atom bombardment-mass spectrum (FAB-MS) of the first fraction (Fig. 2) showed mainly vaccenoylated pentameric LCOs carrying an $N$-methyl and a 6-O-carbamoyl group at the nonreducing end $(\mathrm{m} / \mathrm{z}$ 1313) (NodARc-V(C18:1,Me,Carb)). $[\mathrm{M}+\mathrm{H}]^{+}$ions at $\mathrm{m} / z$ of 1313 , 1445,1459 , and 1591 are molecular ions corresponding to
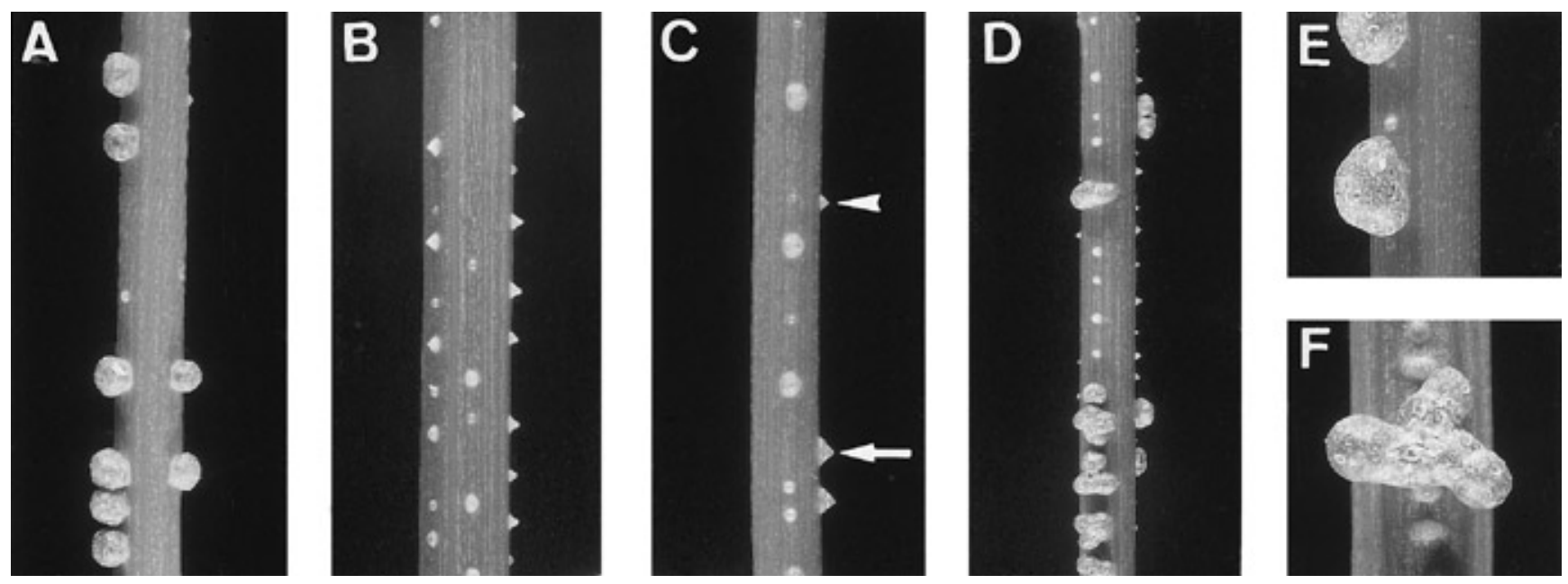

Fig. 1. Sesbania rostrata stem nodulation by ORS571 and derivatives in single and mixed inoculations. A and E, Stems inoculated with Azorhizobiumn caulinodans ORS571 for 7 and 18 days, respectively. B, Stem inoculated with strain ORS571-V44 for 7 days. C, Stem inoculated with ORS571-X15 for 7 days. Arrow and arrowhead indicate a pseudo-nodule and a noninfected adventitious rootlet, respectively. D and F, Stems inoculated with ORS571-V44/ORS571-X15 for 18 days and 4 weeks, respectively. 
LCOs with a reducing end containing no glycosylations, a D-arabinosyl group, an L-fucosyl group, and a D-arabinosyl and L-fucosyl group (NodARc-V(C18:1,Me,Carb,Ara,Fuc)), respectively (Fig. 2) (Mergaert et al. 1997a). A small fraction contained palmitic acid $(\mathrm{m} / \mathrm{z}, 1287)$ instead of vaccenic acid. Indicated ions at $\mathrm{m} / \mathrm{z} 1092,889,686$, and 483 are characteristic fragments originating from cleavage of glycosidic bonds (Fig. 2). The stearoylated fraction contained the same Nod factor population but the masses were two units higher (data not shown). Based on these data, it can be concluded that ORS571-X15 produced the same type of Nod factors as the wild-type strain. Also, the amounts produced were comparable to wild-type levels, as deduced from thin-layer chromatography analysis of ${ }^{14} \mathrm{C}$-labeled LCOs (data not shown).

The mutant strain ORS571-V44 carries a Tn5 insertion in the nodA gene (Van den Eede et al. 1987) that is essential for the synthesis of the LCO backbone. This mutant does not produce Nod factors (Mergaert et al. 1993; Table 1) and is unable to provoke nodules on the host $S$. rostrata ( $\mathrm{Nod}^{-}$phenotype) (Fig. 1B; Table 1). SDS-PAGE followed by silver staining showed the same lipopolysaccharide patterns as in the wild-type strain (data not shown; Table 1).

\section{A nodA-uidA reporter to study bacterial presence in plant tissues.}

The plasmid pRG960SD-32, containing the uidA gene of Escherichia coli (Jefferson 1987), fused to the flavonoidinducible azorhizobial nodA promoter region (Goethals et al. 1989), has been shown previously to be a stable bacterial reporter to study nod gene expression in vitro and to be active in vivo in 5- and 10-day-old $S$. rostrata stem nodules (Van den Eede et al. 1992). A time course experiment was carried out to

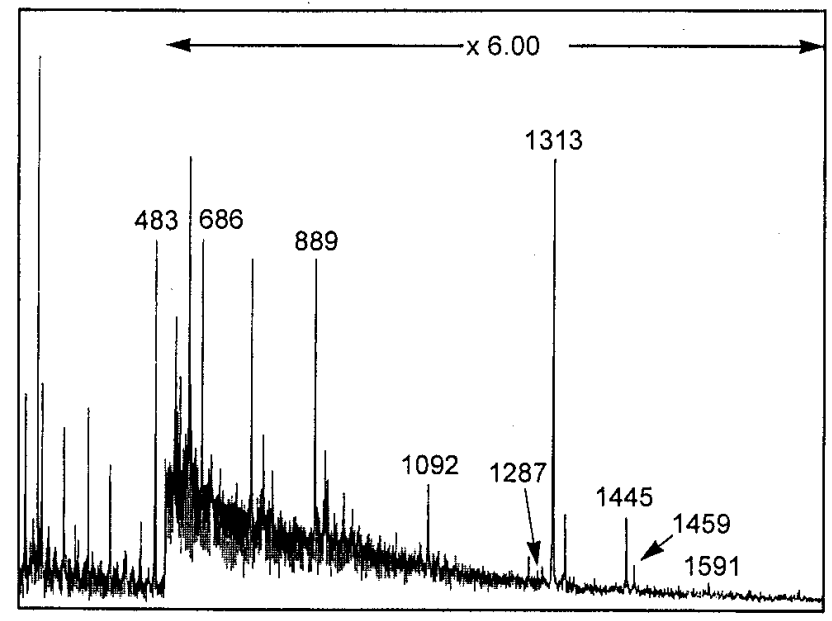

$\mathrm{m} / \mathrm{z}$

Fig. 2. Fast atom bombardment-mass spectrum (FAB-MS) analysis of Nod factors produced by ORS571-X15. $[\mathrm{M}+\mathrm{H}]^{+}$ions at $\mathrm{m} / \mathrm{z}$ of 1313 , 1445,1459 , and 1591 are molecular ions corresponding to lipochitooligosaccharides (LCOs) with a reducing end containing no glycosylations, a D-arabinosyl group, an L-fucosyl group, and both a D-arabinosyl and an L-fucosyl group, respectively (Mergaert et al. 1997a). Ions at $\mathrm{m} / \mathrm{z}$ $1092,889,686$, and 483 are characteristic fragments originating from cleavages of glycosidic bonds. The first fragment $(\mathrm{m} / \mathrm{z}, 1092)$ was caused by the loss of GlcNAc-OH and three other consecutive losses of GlcNAc led to the peaks with $m / z 889,686$, and 483 . The latter molecule corresponded to the nonreducing end of the parental ion (Mergaert et al. 1997a). check GUS activity at later stages of stem nodule development. Nodules induced by ORS571(pRG960SD-32) (Van den Eede et al. 1992) were harvested 10, 20, and 30 days post inoculation and embedded in agarose, and $100-\mu \mathrm{m}$ sections were stained with GUS. In 10- and 20-day-old nodules, a high GUS activity was present in the central tissue (Fig. 3A and B). Sections through 30-day-old, GUS-stained nodules revealed a decrease and disappearance of the GUS activity in the peripheral and central part of the central tissue, respectively (Fig. 3C). These observations confirmed that the nodA-uidA reporter fusion is useful to monitor bacterial presence in developing and in mature stem nodules.

The plasmid pRG960SD-32 was introduced by triparental conjugation into strains ORS571-X15 and ORS571-V44. With a colorimetric GUS assay, the GUS activity of ORS571-X15 (pRG960SD-32) and ORS571-V44(pRG960SD-32) was found to be approximately 10 -fold enhanced in the presence of $20 \mu \mathrm{M}$ naringenin just like in the wild-type strain (Van den Eede et al. 1992).

\section{Invasion phenotype of wild-type and mutant strains.}

With the use of the nodA-uidA expression as a reporter for bacterial presence, the invasion behavior of the wild-type and mutant strains was studied upon inoculation of stem-located, adventitious rootlets of $S$. rostrata. Plant tissues were GUS stained and embedded in Technovit. Semi-thin sections were examined under a light microscope. Reaction products of the hydrolysis of the substrate 5-bromo-4-chloro-3-indolyl- $\beta$-Dglucuronic acid by the GUS enzyme undergo an oxidative dimerization leading to the formation of crystals, which appear as red or blue signals in dark- or bright-field optics, respectively. The red signal in dark-field microscopy, however, changed to blue with increasing signal intensity.

In a transversal section through a young, developing nodule (3 days after inoculation) induced by ORS571(pRG960SD32), approximately 10 infection pockets were present, each with a diameter of approximately $50 \mu \mathrm{m}$ (Fig. 4A). A longitudinal section of a 5-day-old developing nodule observed under bright-field optics (Fig. 4B) shows the occurrence of two nodule lobes, each with a proximal-distal differentiation, with a meristematic region, an invasion zone with numerous infection threads, and a small zone where plant cells are invaded by bacteria (see also Goormachtig et al. 1997). The zone with infected plant cells is obvious in a neighboring section observed under dark-field optics (Fig. 4C).

Transversal sections through pseudo-nodules stained 7 days after inoculation with ORS571-X15(pRG960SD-32) showed the presence of numerous, superficially located infection pockets (Fig. 4D) with sizes similar to those of the infection pockets formed by the wild-type strain. In a longitudinal section, a high GUS activity was present in the peripheral cortical cell layers of the fissure region where bacteria normally enter the plant tissue (Fig. 4F). More detail is seen in a longitudinal section perpendicular to the section shown in Figure 4F. Infection pockets are located two to three cell layers below the surface of the adventitious rootlet (Fig. 4G). A longitudinal section stained with toluidine blue shows that ORS571-X15 could induce the formation of nodule primordia and nodular vascular bundles (Fig. 4E), but neither infection threads nor invaded nodule primordia cells were observed (Fig. 4E and F), nor were they seen at a later stage (data not shown). Nodule 
development seemed to be arrested in the primordium stage and the bacteria were restricted to the superficial cell layers.

Seven days after inoculation with ORS571-V44 (pRG960SD-32), approximately 100 adventitious rootlets of three independent experiments were stained with GUS and examined under the binocular. No GUS signal could be observed. Semi-thin sections were made of five adventitious
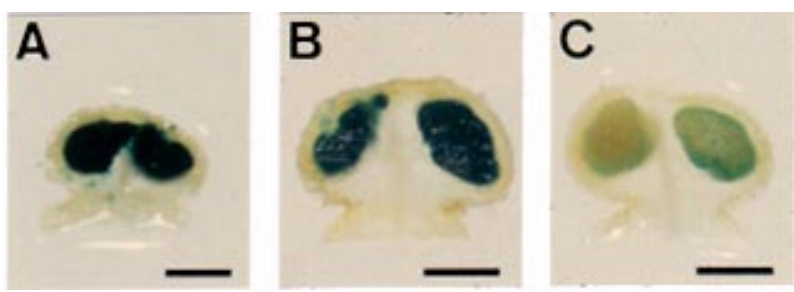

Fig. 3. Sections of nodules formed by ORS571(pRG960SD-32). Nodules were harvested and stained with $\beta$-glucuronidase (GUS), (A) 10 , (B) 20, and (C) 30 days after inoculation. Bars $=1 \mathrm{~mm}$. rootlets, but in none of the sections was any GUS signal present (Fig. 4I and J), showing that ORS571-V44 was not able to invade the cortical cell layers and form infection pockets. Upon inoculation by ORS571-V44(pRG960SD-32), no nodule primordia were formed and no signs of cell division were ever seen in the cortical region of the adventitious rootlets (Fig. 4H). Similar results were obtained with the strain ORS571-V44 (pXLGD4), carrying a constitutively expressed $\beta$-galactosidase reporter gene (Leong et al. 1985) (data not shown).

\section{ORS571-X15 helps ORS571-V44 to invade the developing nodule.}

When the two nodulation-defective strains ORS571-V44 and ORS571-X15 were coinoculated in a one-to-one proportion, nodules were formed. These nodules appeared later than normal and were less numerous than in wild-type inoculations: approximately $8 \%$ of the inoculated adventitious rootlets developed into a nodule whereas for a wild-type nodulation this was around $80 \%$. The nodules became multi-lobed
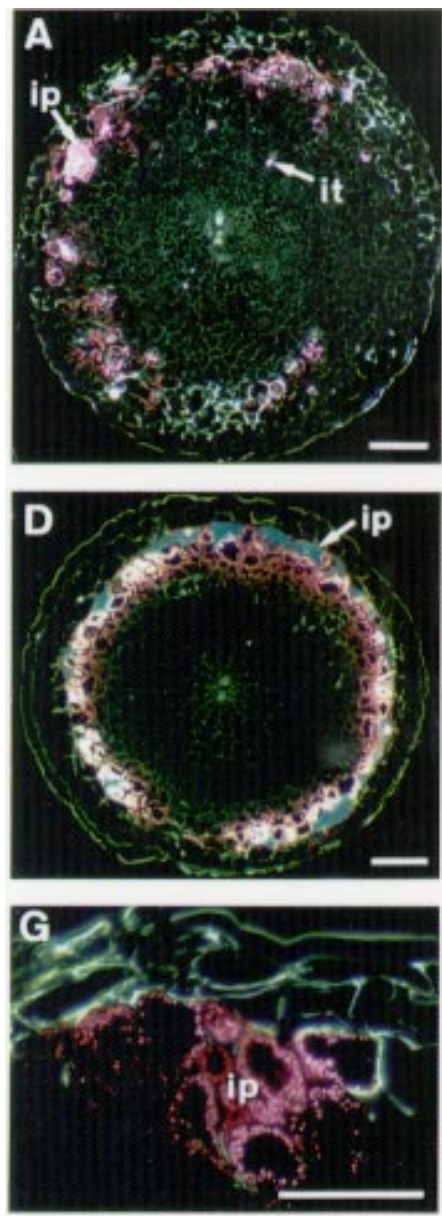
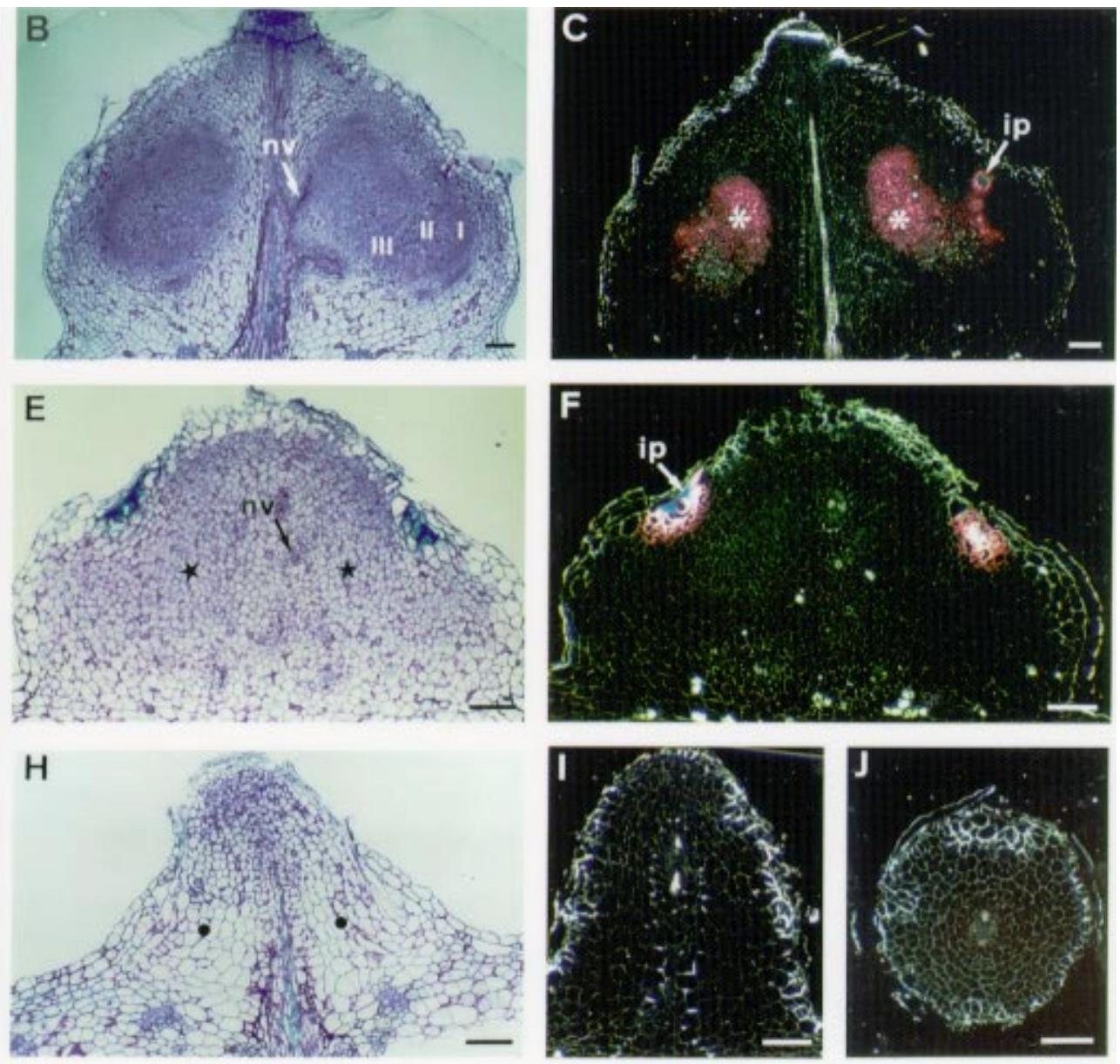

Fig. 4. Sections of developing nodules formed by ORS571(pRG960SD-32), pseudo-nodules induced by ORS571-X15(pRG960SD-32), and dormant adventitious rootlets inoculated with ORS571-V44(pRG960SD-32). A, Dark-field micrograph of a transversal section of a young developing nodule (3 days after inoculation) formed by ORS571(pRG960SD-32). B-C, Bright- and dark-field micrographs of a longitudinal section of a developing nodule (5 days after inoculation). Meristematic zone, invasion zone, and zone containing infected cells are indicated in B with I, II, and III, respectively. C, Asterisks indicate central tissue with infected plant cells. D-G, Dark- and bright-field micrographs of (D) transversal and (E-G) longitudinal sections of 7-day-old pseudo-nodules. E, Stars indicate nodule primordia. G, Longitudinal section is enlargement of infection pocket region and is taken in a direction perpendicular to that of the longitudinal section in $\mathbf{F}$. H-J, Bright- and dark-field micrographs of $(\mathbf{H}, \mathbf{I})$ longitudinal and $(\mathbf{J})$ transversal sections of an adventitious rootlet inoculated with ORS571-V44(pRG960SD-32). H, Dots indicate cortical tissue. Toluidine blue-stained sections were alternated with sections for dark-field microscopy. Abbreviations: ip, infection pocket; it, infection thread; nv, nodule vascular bundle. Bars $=100 \mu \mathrm{m}$. 

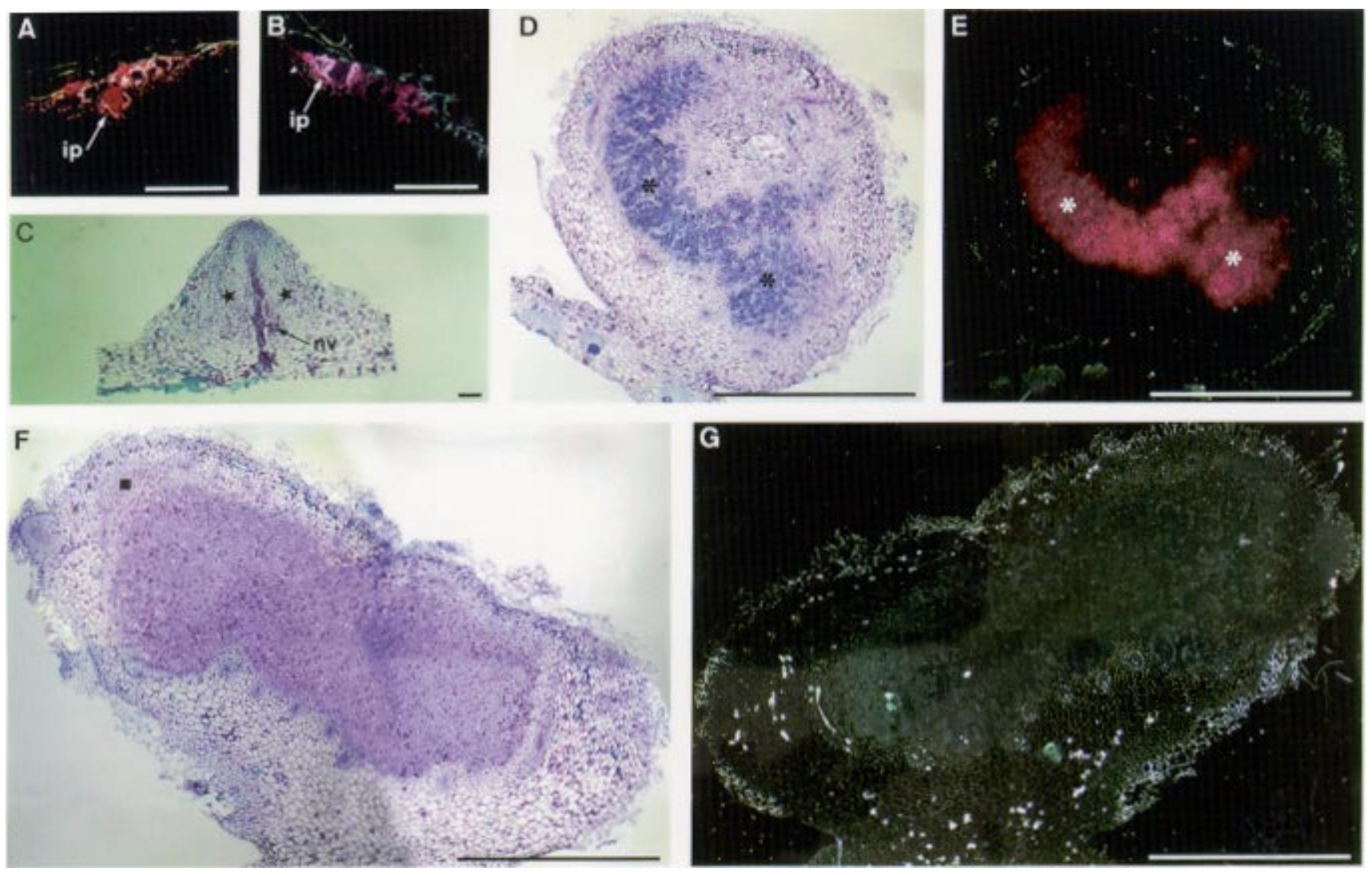

Fig. 5. Sections of nodules formed upon a mixed inoculation with ORS571-V44 and ORS571-X15. Bright- and dark-field micrographs of secti ons of (A-C) 3-day-old developing nodules and (D-G) 3-week-old nodules. Mixed inoculations were carried out with either (B-E) ORS571-V44 or (A, F, G) ORS571-X15 carrying pRG960SD-32. C and F, Stars and square indicate nodule primordia and a meristematic zone, respectively. D and E, Asterisks show central tissue with infected plant cells. Toluidine blue-stained sections were adjacent to the ones observed with dark-field microscopy. Abbreviations: ip, infection pocket; nv, nodule vascular bundle. Bars $=100 \mu \mathrm{m}$.
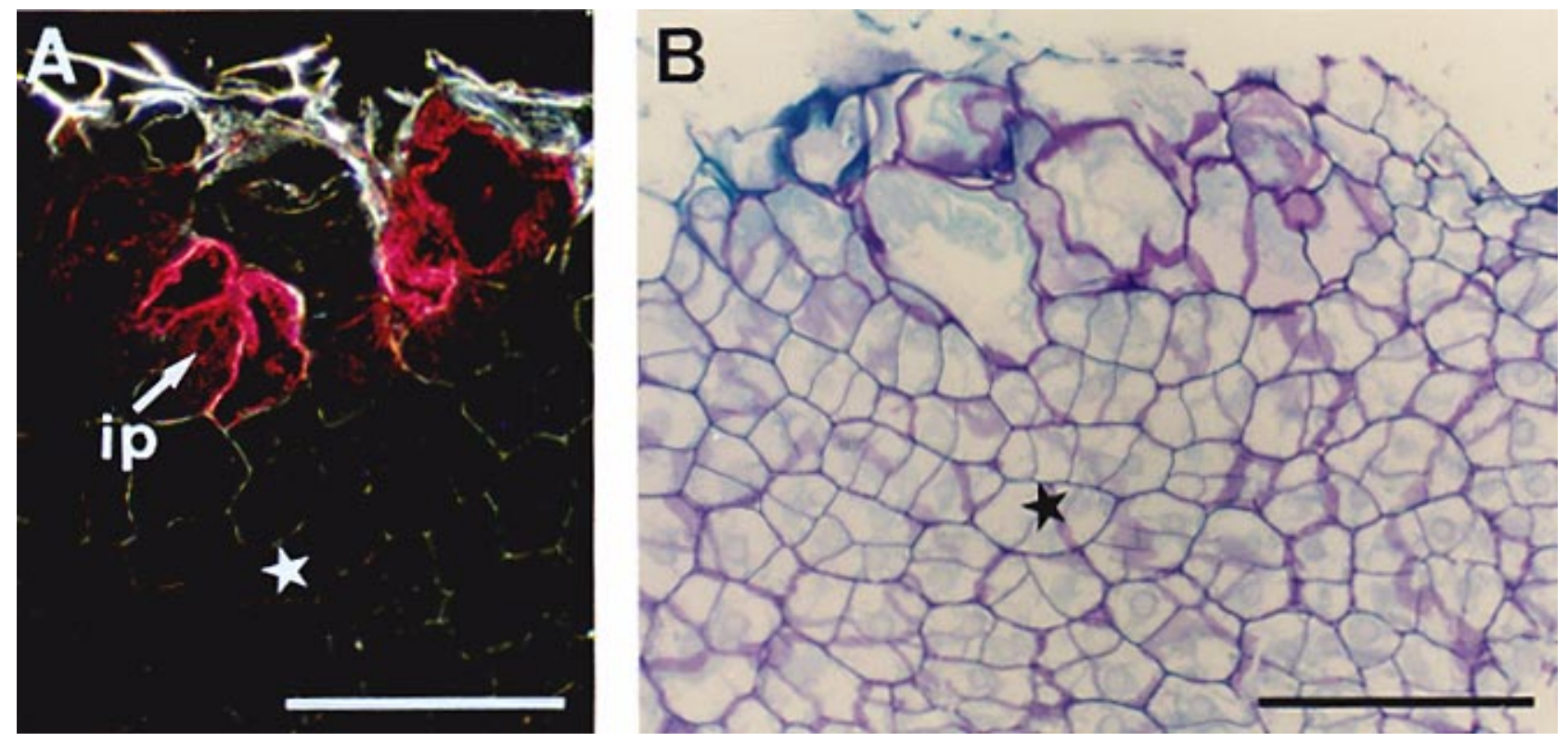

Fig. 6. Infection pockets formed upon complementation of ORS571-V44(pRG960SD-32) by Nod factors. A, Dark-field micrograph of a longitudinal section 9 days after inoculation. B, A neighboring section stained with toluidine blue. Stars indicate nodule primordia. Abbreviations: ip, infection pocket. Bars $=100 \mu \mathrm{m}$ 
(Fig. 1D and F), in contrast to wild-type nodules, which remained regular and round (Fig. 1A and E). Plants developing such multi-lobed nodules did not show any signs of nitrogen starvation and the nodule interior showed a red color, characteristic for the presence of leghemoglobins. These observations indicated that the nodules were functional.

To determine which mutant strain occupied the nodules, mixed inoculations were performed with either ORS571-X15 or ORS571-V44 carrying a chromosomal rifampicin resistance marker. Surface-sterilized, 10-day-old nodules were crushed and the content was plated on a selective medium with and without rifampicin. For the ORS571-V44 ${ }^{\text {rif/ }}$ ORS571-X15 coinoculation, approximately $10^{6}$ to $10^{7}$ colonies per nodule grew on media with or without rifampicin, whereas for the ORS571-V44/ORS571-X15 ${ }^{\text {rif }}$ inoculation, no colonies grew on medium with, and $10^{6}$ to $10^{7}$ colonies on medium without, rifampicin. Reisolated bacteria were reinoculated on the host plant and could not induce nodule for-
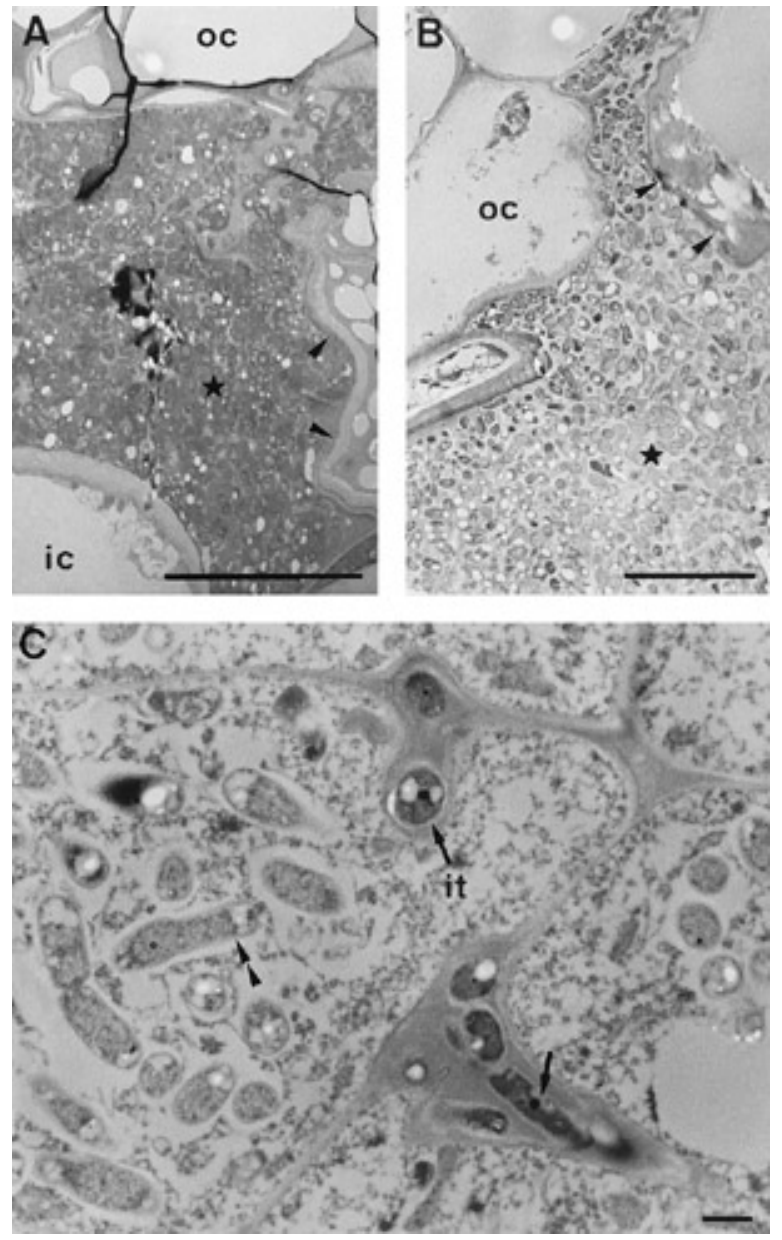

Fig. 7. Transmission electron microscopy images of infection pockets and internalized cells. A and B, Infection pockets of a 7-day-old pseudo-nodule and an 8-day-old nodule formed upon an inoculation with the mixture ORS571-V44/ORS571-X15. Arrowheads show a collapsing cell. Stars indicate bacteria present in the infection pocket. $\mathbf{C}$, Infected plant cells in meristematic zone of a nodule formed by a mixed inoculation. A bacteroid and an internalizing bacterium are indicated with superimposed arrowheads and an arrow, respectively. Abbreviations: ic, inner cortex; it, infection thread; oc, outer cortex. Bars $=(\mathbf{A}$ and B) $10 \mu \mathrm{m}$ and (C) $1 \mu \mathrm{m}$. mation, showing that the complementation nodules were not caused by rare revertants of the Tn 5 insertion. Thus, no ORS571-X15 bacteria could be reisolated from the surface-sterilized nodules, suggesting that the central tissue of the nodules formed by a coinoculation was exclusively occupied by ORS571-V44. However, ORS571-X15 could still have been present in peripheral tissues and been killed by the surface sterilization procedure. Therefore, the presence of bacteria was examined in more detail with the reporter plasmid pRG960SD-32. Two sets of mixed inoculations were performed with either ORS571-X15 or ORS571-V44 carrying the plasmid pRG960SD-32, and 3- and 10-day-old nodules were stained with GUS, embedded, and sectioned as previously described. Images representative of the observations are shown in Figure 5.

Three days after inoculation, in both sets of mixed inoculations a high GUS activity was observed in the peripheral, cortical cell layers of the developing nodule (Fig. 5A and B). Transversal sections showed that this activity was associated with a restricted number of infection pockets, as in ORS571(pRG960SD-32) infections, different from the extensive concentric staining observed in single inoculations with ORS571-X15(pRG960SD-32) (data not shown). Infection pockets were occupied by both strains (Fig. 5A and B), suggesting that colonization of the peripheral, cortical cell layers by ORS571-V44 was facilitated by ORS571-X15, because in a single infection ORS571-V44 was unable to reach these cell layers (Fig. 4I and J). Sections stained with toluidine blue showed the presence of nodule vascular bundles and regions with small, dividing cells, indicating the formation of nodule primordia (Fig. 5C). At this early stage, no infection threads could be observed whereas, in developing nodules induced by the wild-type strain, bacteria had already reached the nodule primordia via the infection threads (Fig. 4A). This indicates that nodule formation upon mixed inoculation was delayed.

Three weeks after inoculation, ORS571-X15-associated GUS activity could no longer be observed (Fig. 5G). ORS571-V44-associated GUS activity was seen in the central tissue where bacteria became internalized as bacteroids (Fig. 5D and E). Development was different when compared with wild-type nodules, with longer lasting meristematic activity and an unusual degree of asymmetry (Fig. 5D and F).

Mixed inoculations with threefold more ORS571-X15 than ORS571-V44 instead of equal amounts were carried out as well. Functional nodules still developed but with less frequency. The spatial presence of bacteria in the complementation nodules was similar to the one just described (data not shown).

\section{Infection pocket formation after coinoculation of ORS571-V44 and purified Nod factors.}

In order to prove that Nod factors are determinant factors in intercellular infection, an experiment was designed to simultaneously treat stem-located, adventitious rootlets with purified Nod factors and the nodA mutant strain ORS571-V44 (see Material and Methods). NodARc-V (C18:1,Me,Carb) and NodARc-V(C18:1,Me,Carb,Ara,Fuc) were supplied at final concentrations of $0.5 \times 10^{-7}$ and $1 \times 10^{-7} \mathrm{M}$, respectively. To this solution, an ORS571-V44 (pRG960SD-32) culture was added at a final concentration of $10^{8}$ cells per ml. As a control, stems were treated as described above, but without Nod factors.

Nine days after inoculation, plant tissue was harvested, stained with GUS, and embedded. Longitudinal sections re- 
vealed the formation of infection pockets that were occupied by bacteria (Fig. 6A). In toluidine blue-stained sections, cell division was observed opposite of the infection pockets, indicating that nodule primordia were induced (Fig. 6B). Adventitious rootlets of control stems solely inoculated with ORS571-V44 (pRG960SD-32) were examined 9 days after inoculation and did not show any of these responses (data not shown). These observations confirmed that Nod factors are required to allow azorhizobia to invade the plant tissue.

\section{Ultrastructural analysis of infection pockets and infected plant cells.}

Light microscope observations indicated the presence of superficial infection pockets in pseudo-nodules induced by ORS571-X15 and in nodules formed upon a mixed inoculation with ORS571-X15 and ORS571-V44. However, it was still questionable whether bacteria occurred intracellularly as described for infection pockets created by ORS571 (Tsien et al. 1983; Duhoux 1984) or eventually also intercellularly. Therefore, transversal sections of 7-day-old pseudo-nodules and 8-day-old nodules formed upon a mixed inoculation were examined in more detail by transmission electron microscopy. In Figure 7A, a transmission electron microscopy picture of an infection pocket induced by ORS571-X15(pRG960SD-32) is shown. The pocket was confined in the upper part by flattened outer cortical cells with folded cell walls and a degenerated and condensed cytoplasm. In the lower part, welldifferentiated, inner cortical cells were present (Fig. 7A). ORS571-X15 bacteria were surrounded by high electron-dense matrix material. A collapsing plant cell with a folded cell wall was observed (Fig. 7A) that was loosened from the adjacent cell at the level of the middle lamella (data not shown). The cytoplasm of the collapsing cell contained high electron-dense material and several low electron-dense vesicles presumably originating from the vacuole. The electron density of the degenerated cytoplasm and of the matrix material surrounding the bacteria inside the infection pocket were comparable. No bacteria could be observed inside intact plant cells. Infection pockets formed upon a mixed inoculation showed characteristics similar to those of infection pockets induced by ORS571-X15 in a single infection (Fig. 7B), but the majority of the azorhizobia present in the infection pocket were surrounded by a layer of low electron-dense material (Fig. 7B). Intercellular infection threads guided bacteria from the infection pockets toward the nodule primordia; intracellular infection threads were observed near the meristematic zone, where internalization occurred, identical to the invasion procedure of the wild-type strain (Fig. 7C).

\section{DISCUSSION}

We have studied the invasion behavior of $A$. caulinodans in cortical root tissues of young, adventitious rootlets located on the $S$. rostrata stem. To localize bacteria, a uidA reporter gene was fused to the nodA promoter region. The nodA promoter was active from the very start of the interaction and uidA-encoded GUS activity was still present in the mature 20-day-old nodules (Van den Eede et al. 1992; this work). This activity could be the consequence of the combination of promoter activity and enzyme stability. GUS is a very stable enzyme with a half-life of $50 \mathrm{~h}$ in living mesophyll protoplasts
(Jefferson et al. 1987) and its activity could still be observed days after transcription was arrested (De Block and Debrouwer 1992). Nevertheless, the long-lasting activity in 20-day-old nodules is probably also due to promoter activity in the bacteroids. Sharma and Signer (1990) described a GUS activity directed by the nodA promoter of Rhizobium meliloti in the central tissue of 17-day-old alfalfa nodules. In pea nodules, however, no nod gene transcripts could be detected in bacteroids (Schlaman et al. 1991), showing that in this case the nod promoter was not functional. Preliminary data indicate that the expression of the nodA-uidA reporter in 18-day-old stem nodules is independent of the regulatory NodD protein (M. Gao, W. D'Haeze, and M. Holsters, unpublished data). Moreover, 125 and 12 bp upstream, respectively, from the nod box consensus sequence, NifA and $\sigma^{54}$ binding sites (reviewed by Fischer 1994) were found (W. D'Haeze, M. Gao, and M. Holsters, unpublished data). NifA works together with a $\sigma^{54}$ factor and is the major transcriptional activator of the nif operons that encode proteins involved in nitrogen fixation (reviewed by Fischer 1994). Recently, Freiberg et al. (1997) have found both a nod box and a NifA- $\sigma^{54}$-type promoter in an operon present on the symbiotic plasmid pNGR234a of Rhizobium sp. NGR234. The presence of these novel consensus sequences suggests a new type of transcriptional regulation.

We compared the invasion of three strains, the wild-type strain ORS571, a nodA mutant that makes no Nod factors, and an SPS-changed mutant. This comparison led to the conclusion that intact nod genes are required for primary bacterial intercellular invasion. There was a big difference between the invasion behavior of the three strains. ORS571-V44 showed not the slightest sign of intercellular infection. This observation came somewhat as a surprise because of reports of nod gene-independent crack entry of $A$. caulinodans at lateral root junctions of $S$. rostrata roots (Gough et al. 1997; O'Callaghan et al. 1997). The mutant ORS571-X15, which produces a normal LCO population, colonized the outer cortical cell layers, but was arrested and did not go deeper; there were no traces of inter- or intracellular infection threads. For an as yet unknown reason, the colonization of the outer cortex was more extensive, perhaps less specific, than with the wild type. ORS571-X15 induced the formation of a concentric zone of infection pockets and nodule primordia. Thus, the wild-type SPS are essential for deeper invasion and perhaps also to delimit the primary colonization. LCO production, on the other hand, is essential to allow colonization of the outer cortical region. It could still be argued that apart from their role in Nod factor production, nod gene products also play a role in altering SPS (Cedergren et al. 1995; Forsberg and Reuhs 1997). However, ORS571-X15 has a dramatically altered outer surface, which is very unlikely to be a substrate for nod gene-dependent functional modifications.

More information about the contribution of Nod factors and SPS to host plant infection was deduced from mixed inoculations of the nodA mutant strain ORS571-V44 and the SPS mutant ORS571-X15, leading to functional nodules, the central tissues of which were exclusively occupied by the nodA mutant. This observation shows that also in an intercellular infection Nod factors open the door to the bacteria and allow a nodA mutant (with the correct outer surface) to go inside, as previously described for root hair infection (Relić et al. 1994). 
The mutant ORS571-X15 can be considered a peripherally located Nod factor factory. Nod factors are not required for deeper invasion, assuming (based on their physicochemical properties) that they are not likely to move over long distances in plant tissues and therefore would remain at the place of production, the peripheral cortical cell layers. Also, putative nod gene-dependent SPS modifications are not essential for deeper invasion because there is no functional nod gene expression by the invading nodA mutant strain. The nodA mutant can be internalized by plant cells; thus, except when Nod factors would stick to the outside of ORS571-V44, neither Nod factors nor nod gene-dependent SPS alterations are essential for endocytosis, confirming the conclusions reached by Relić et al. (1994) in their study of Vigna unguiculata nodulation. The ultimate proof of an involvement of Nod factors in intercellular infection came from a treatment of stem-located, adventitious rootlets with a mixture of Nod factors and ORS571-V44 bacteria, leading to the formation of bacteriafilled infection pockets.

The SPS of ORS571 seem to play a role in the control of the primary intercellular invasion. The colonization by ORS571-X15 of outer cortical regions was much more elaborate than that by the wild-type strain, but upon coinoculation of ORS571-X15 and ORS571-V44 the colonization pattern resembled that of the wild-type strain. This observation indicates that the wild-type SPS of ORS571-V44 might be involved in eliciting a plant response to limit lateral spreading of the invasion in the outer cortex, perhaps by suppressing plant defense responses that are triggered by Nod factors. The reason why the mutant strain ORS571-X15 is incapable of deeper invasion via infection threads is presently unknown. The strain shares characteristics of pleiotropic exo mutants of Rhizobium leguminosarum bv. viciae described by van Workum et al. (1995) that are affected in exopolysaccharide synthesis as well as in somatic SPS (lipopolysaccharides and probably also in capsular polysaccharides) and that also cannot be helped by another strain to invade the host tissues. Clearly, in both systems, to invade the plant, the proper somatic SPS are needed even though the way is made by a helper strain. In contrast, alfalfa plants coinoculated with $R$. meliloti nodulation mutants and infection mutants, deficient in exopolysaccharide synthesis production only, formed mixed infected nodules with both mutants present (Klein et al. 1988; Kapp et al. 1990).

At later stages of nodule development, the GUS activity in the outer cortex regions disappeared in all marked strains. Preliminary results with an ORS571(pXLGD4) strain that carries a constitutive marker gave the same results (M. Gao, W. D'Haeze, and M. Holsters, unpublished data). Therefore, the transiency of the GUS stain indicates a loss of bacterial viability rather than a repressed nod promoter activity and could be an indication that a general defense response is directed specifically toward bacteria located in external cortical layers or that bacteria lose viability after exhaustion of nutrient supply.

The electron microscopic analysis of superficially localized infection pockets showed that they consist of extracellular bacteria often surrounding collapsing plant cells. This is reminiscent of observations made for Stylosanthes spp. in which bacteria reached the site of nodule initiation by progressive collapse of plant cells (Chandler et al. 1982). This raises the intriguing question as to how infection pockets are formed and how space is made for the massive cortical colonization of bacteria. Further investigations will address the question whether bacteria induce localized necrosis of plant cells or whether programmed cell death could be involved.

Sound conclusions can be reached about a role for Nod factors in early invasion, but how about their involvement in the later stages of nodule development? In the complementation nodules, the central tissue, which is occupied by the nodA mutant, showed an aberrant development with chaotic nodule tissue organization. The nodA promoter of A. caulinodans is active in bacteroids present in mature nodules; therefore, during wild-type nodulation, LCOs could be produced that may be important for the coordinated progression of nodule development. Recently, Timmers et al. (1998) presented evidence for Nod factor internalization in the cytoplasm of infected plant cells. These authors suggested that Nod factors would affect cytoskeletal changes and nodule development, as microtubular cytoskeleton disorganization occurred in the same region. This interesting hypothesis would implicate a disorganized development of nodules occupied by a non-Nod factor-producing strain and this is precisely what we have observed. However, besides Nod factors, other signals emanating from the bacteria may also play a role because the invasion of a nodA mutant triggers progression of nodule development beyond the nodule primordium stage.

The major conclusions of this work are that Nod factors open the door for intercellular invasion of azorhizobia in peripheral tissues of $S$. rostrata, that SPS are necessary to progress deeper into plant tissues, and that proper nodule development is dependent on continued Nod factor production as well as on other, as-yet-unidentified, bacterial signals.

\section{MATERIAL AND METHODS}

\section{Growth conditions and bacterial strains.}

Azorhizobium caulinodans ORS571, ORS571-X15 (Goethals et al. 1994), and ORS571-V44 (Van den Eede et al. 1987) were grown at $37^{\circ} \mathrm{C}$ in YEB medium (Geremia et al. 1994) containing the appropriate antibiotics. For a large-scale Nod factor preparation and for a colorimetric GUS assay azorhizobial strains were cultured in MMO (Goethals et al. 1989) and LSR (Van den Eede et al. 1987) media, respectively. nod genes were induced with $20 \mu \mathrm{M}$ naringenin. Escherichia coli strains were grown at $37^{\circ} \mathrm{C}$ in Luria Bertani medium (Sambrook et al. 1989). Antibiotics were applied in the following concentrations for A. caulinodans and E. coli strains (all per ml): $200 \mu \mathrm{g}$ of carbenicillin, $50 \mu \mathrm{g}$ of kanamycin, $100 \mu \mathrm{g}$ of spectinomycin, $20 \mu \mathrm{g}$ of streptomycin, and 50 $\mu \mathrm{g}$ of rifampicin.

ORS571(pRG960SD-32) was described by Van den Eede et al. (1992). The plasmid pRG960SD-32 was mobilized to ORS571-X15 and ORS571-V44 by triparental mating with pRK2013 (Ditta et al. 1980) as a helper plasmid. By the same procedure, plasmid pXLGD4, carrying a constitutively expressed lacZ gene (Leong et al. 1985), was introduced into ORS571 and ORS571-V44.

Rifampicin-resistant derivatives of ORS571-X15 and ORS571-V44, indicated as ORS571-X15 $5^{\text {rif }}$ and ORS571-V44 ${ }^{\text {rif }}$, respectively, were obtained by selection on a YEB medium supplied with $50 \mu \mathrm{g}$ of rifampicin per $\mathrm{ml}$. 


\section{Nod factor preparation and analysis.}

In vivo labeling of Nod factors, analysis by thin-layer chromatography, and quantification were carried out as described by Mergaert et al. (1995). A large-scale Nod factor preparation from a 10-liter ORS571-X15 culture and FAB-MS analysis of the purified products were done as previously described for the ORS571 wild-type strain (Mergaert et al. 1997a).

\section{Plant growth and stem inoculations.}

S. rostrata seeds were surface sterilized and germinated (Goethals et al. 1989). Per pot, three plants were cultivated and, after 4 weeks, stems were inoculated with azorhizobia as described by Goormachtig et al. (1995).

Azorhizobia were reisolated from nodules as described by Van den Eede et al. (1987). The contents of five nodules were plated independently, the number of colonies growing on selective media were determined, and the average was taken and presented in the Results.

For mixed inoculations with purified Nod factors and ORS571-V44(pRG960SD-32), the dormant root meristems of adventitious rootlets were decapitated to avoid root formation. Approximately 50 adventitious rootlets were treated per stem. The stems were bent horizontally and kept in an open plastic tube filled with water; Nod factors and bacteria were added in the appropriate concentrations. To overcome evaporation of the solution, water was added to the tube every $8 \mathrm{~h}$. As a control, stems were treated as described above but without Nod factors. To ensure that the observed phenotype was not caused by reversion or cross contamination with ORS571, a fraction of the solution was plated on a medium containing 5-bromo-4-chloro-3-indolyl- $\beta$-D-glucuronic acid. Only blue colonies were observed. Several colonies were pooled and used to reinfect stems and in all the cases a Nod $^{-}$phenotype was observed.

\section{GUS and X-Gal assays and light microscopy.}

Quantitative GUS assays were carried out according to Van den Eede et al. (1992).

Developing nodules, nodules, pseudo-nodules, and (inoculated) adventitious rootlets were harvested at the appropriate times. Plant tissues were immersed in cold $90 \%$ acetone during $30 \mathrm{~min}$ under rotation at $4^{\circ} \mathrm{C}$ and washed with phosphate buffer $\left(0.2 \mathrm{M} \mathrm{NaH}_{2} \mathrm{PO}_{4}\right.$ and $0.2 \mathrm{M} \mathrm{Na}_{2} \mathrm{HPO}_{4} \cdot 7 \mathrm{H}_{2} \mathrm{O}$, pH 7.2) for $15 \mathrm{~min}$. This step was performed three times. The solution was replaced by $1 \mathrm{ml}$ of phosphate buffer. Optionally, $10 \mu \mathrm{l}$ of $10 \mathrm{mM} \mathrm{K} \mathrm{Fe}_{4}(\mathrm{CN})_{6} \cdot 3 \mathrm{H}_{2} \mathrm{O} / \mathrm{K}_{3} \mathrm{Fe}(\mathrm{CN})_{6}$ solution was added and another incubation for 15 to $30 \mathrm{~min}$ was carried out under rotation. Next, $50 \mu \mathrm{l}$ of $10 \mathrm{mg}$ of 5-bromo-4-chloro-3indolyl- $\beta$-D-glucuronic acid solution was added and the mixture was vacuum infiltrated for 1 to $3 \mathrm{~h}$. Hereafter, samples were shaken for $1 \mathrm{~h}$ at $37^{\circ} \mathrm{C}$ in the dark and incubated at $37^{\circ} \mathrm{C}$ for 1 to $12 \mathrm{~h}$. In order to avoid overstaining, the GUS staining was checked every $2 \mathrm{~h}$ by observing the plant tissue with a binocular (Leitz, Heerbrugg, Switzerland). After three 10-min washes with phosphate buffer, $1 \mathrm{ml}$ of $2.5 \%$ glutaraldehyde in phosphate buffer was added, and the samples were fixed under rotation for at least $12 \mathrm{~h}$ at room temperature. The fixation procedure was followed by three washes in phosphate buffer for $15 \mathrm{~min}$. Dehydration was done in a series of 10, 30, and $50 \%$ ethanol during $30 \mathrm{~min}$ and in $70 \%$ ethanol overnight, with rotation and at room temperature.
The staining procedure with 5-bromo-4-chloro-3-indolyl- $\beta$ D-galacto-pyranoside (X-Gal) was similar to that of GUS, but the phosphate buffer was replaced by $0.1 \mathrm{M}$ Na-cacodylate ( $\mathrm{pH} 7.4)$. After the acetone treatment, the tissue was prefixed in $2.5 \%$ glutaraldehyde in $0.1 \mathrm{M}$ cacodylate buffer, overnight at room temperature. The staining was done in $1 \mathrm{ml}$ of $0.1 \mathrm{M}$ cacodylate buffer supplied with $20 \mu \mathrm{l}$ of a $40 \mathrm{mg} / \mathrm{ml} \mathrm{X-Gal}$ stock solution.

Plant tissue was embedded in 5\% agarose and sectioned as described by Van den Eede et al. (1992) or in Technovit 7100 (Kulzer Histo-Technik, Wehrheim, Germany) according to the manufacturer's instructions. In the latter case, 2- $\mu$ m sections were cut on a microtome (Reichert-Jung, Nussloch, Germany) and mounted on Vectabond-coated slides (Sigma, St. Louis, MO). Every other section was stained with $0.5 \%$ toluidine blue for morphological analysis (O'Brien et al. 1964). After air drying, sections were mounted. Photographs were taken with a Diaplan microscope equipped with bright- and dark-field optics (Leitz, Wetzlar, Germany).

\section{Electron microscopy.}

Samples for electron microscopy were slightly stained with GUS to observe bacterial presence during sectioning. The staining was done as described above, but the acetone treatment was omitted and the second incubation at $37^{\circ} \mathrm{C}$ was shorter. When a blue signal was observed, plant tissue was washed three times with $0.1 \mathrm{M} \mathrm{Na}$-cacodylate ( $\mathrm{pH}$ 7.2) for 15 min at room temperature under rotation. The solution was changed for fixative solution $(2.5 \%$ formaldehyde and $2.5 \%$ glutaraldehyde in $0.1 \mathrm{M} \mathrm{Na}$-cacodylate) and the samples were vacuum infiltrated for $4 \mathrm{~h}$ at room temperature. Fresh fixative solution was added and the samples were incubated under rotation at $4^{\circ} \mathrm{C}$ for at least $14 \mathrm{~h}$. Samples were dehydrated in an ethanol series under rotation at $4^{\circ} \mathrm{C}$ as follows: $30 \%$ ethanol for $2 \mathrm{~h}, 50 \%$ ethanol for $2 \mathrm{~h}, 70 \%$ ethanol overnight, $95 \%$ ethanol for $2 \mathrm{~h}$, and $95 \%$ ethanol overnight. Then, the plant tissue was embedded in LR White hard grade (London Resin, Basingstoke, UK) by successive incubations under rotation at $4^{\circ} \mathrm{C}$ as follows: overnight in $1 / 1(\mathrm{vol} / \mathrm{vol})$ ethanol/LR White and three times for at least $8 \mathrm{~h}$ in pure LR White. Hereafter, samples were transferred to capsules with LR White and polymerization was performed by UV illumination for $48 \mathrm{~h}$ at $4^{\circ} \mathrm{C}$ and for $24 \mathrm{~h}$ at $65^{\circ} \mathrm{C}$. Serial sections were made on a Ultracut microtome (Reichert-Jung) with a diamond knife. For light microscopy, a Diaplan microscope on phase contrast optics was used. Sections, collected on collodion-coated $\mathrm{Cu}$ grids, were stained with $2 \%$ uranyl acetate for $12 \mathrm{~min}$ and examined by transmission electron microscopy (Elmiscope 101; Siemens, Karlsruhe, Germany).

\section{ACKNOWLEDGMENTS}

We thank J.-C. Promé (Centre National de la Recherche Scientifique, Toulouse, France) for help with the Nod factor analysis, Peter Mergaert for critical reading of the manuscript, Christa Verplancke for growing Sesbania rostrata plants, Martine De Cock for help with the manuscript, and Karel Spruyt, Christiane Germonprez, and Rebecca Verbanck for artwork and photographs. W. D. is indebted to the Vlaams Instituut voor de Bevordering van het Wetenschappelijk-Technologisch Onderzoek in de Industrie for a predoctoral fellowship. G. E. and M. H. are a Research Engineer and a Research Director of the Institut National de la Recherche Agronomique (France) and the Fund for Scientific Research (Flanders), respectively. 


\section{LITERATURE CITED}

Bauer, W. D. 1981. Infection of legumes by rhizobia. Annu. Rev. Plant Physiol. 32:407-449.

Cedergren, R. A., Lee, J., Ross, K. L., and Hollingsworth, R. I. 1995. Common links in the structure and cellular localization of Rhizobium chitolipooligosaccharides and general Rhizobium membrane phospholipid and glycolipid components. Biochemistry 34:4467-4477.

Chandler, M. R., Date, R. A., and Roughley, R. J. 1982. Infection and root-nodule development in Stylosanthes species by Rhizobium. J. Exp. Bot. 33:47-57.

De Block, M., and Debrouwer, D. 1992. In-situ enzyme histochemistry on plastic-embedded plant material. The development of an artefact-free $\beta$-glucuronidase assay. Plant J. 2:261-266.

Dénarié, J., Debellé, F., and Promé, J.-C. 1996. Rhizobium lipochitooligosaccharide nodulation factors: Signaling molecules mediating recognition and morphogenesis. Annu. Rev. Biochem. 65: 503-535.

Ditta, G., Stanfield, S., Corbin, D., and Helinski, D. R. 1980. Broad host range DNA cloning system for Gram-negative bacteria: Construction of a gene bank of Rhizobium meliloti. Proc. Natl. Acad. Sci. USA 77: 7347-7351.

Duhoux, E. 1984. Ontogénèse des nodules caulinaires du Sesbania rostrata (légumineuses). Can. J. Bot. 62:982-994.

Fischer, H.-M. 1994. Genetic regulation of nitrogen fixation in rhizobia. Microbiol. Rev. 58:352-386.

Forsberg, L. S., and Reuhs, B. L. 1997. Structural characterization of the $\mathrm{K}$ antigens from Rhizobium fredii USDA257: Evidence for a common structural motif, with strain-specific variation, in the capsular polysaccharides of Rhizobium spp. J. Bacteriol. 179:5366-5371.

Freiberg, C., Fellay, R., Bairoch, A., Broughton, W. J., Rosenthal, A., and Perret, X. 1997. Molecular basis of symbiosis between Rhizobium and legumes. Nature (London) 387:394-401.

Gage, D. J., Bobo, T., and Long, S. R. 1996. Use of green fluorescent protein to visualize the early events of symbiosis between Rhizobium meliloti and alfalfa (Medicago sativa). J. Bacteriol. 178:7159-7166.

Geremia, R. A., Mergaert, P., Geelen, D., Van Montagu, M., and Holsters, M. 1994. The NodC protein of Azorhizobium caulinodans is an $\mathrm{N}$-acetylglucosaminyltransferase. Proc. Natl. Acad. Sci. USA 91: 2669-2673.

Goethals, K., Gao, M., Tomekpe, K., Van Montagu, M., and Holsters, M. 1989. Common nodABC genes in Nod locus 1 of Azorhizobium caulinodans: Nucleotide sequence and plant-inducible expression. Mol Gen. Genet. 219:289-298.

Goethals, K., Leyman, B., Van den Eede, G., Van Montagu, M., and Holsters, M. 1994. An Azorhizobium caulinodans ORS571 locus involved in lipopolysaccharide production and nodule formation on Sesbania rostrata stems and roots. J. Bacteriol. 176:92-99.

Goormachtig, S., Alves-Ferreira, M., Van Montagu, M., Engler, G., and Holsters, M. 1997. Expression of cell cycle genes during Sesbania rostrata stem nodule development. Mol. Plant-Microbe Interact. 10: 316-325.

Goormachtig, S., Valerio-Lepiniec, M., Szczyglowski, K., Van Montagu, M., Holsters, M., and de Bruijn, F. J. 1995. Use of differential display to identify novel Sesbania rostrata genes enhanced by Azorhizobium caulinodans infection. Mol. Plant-Microbe Interact. 8:816-824.

Gough, C., Galera, C., Vasse, J., Webster, G., Cocking, E. C., and Dénarié, J. 1997. Specific flavonoids promote intercellular root colonization of Arabidopsis thaliana by Azorhizobium caulinodans ORS571. Mol. Plant-Microbe Interact. 10:560-570.

Heidstra, R., and Bisseling, T. 1996. Nod factor-induced host responses and mechanisms of Nod factor perception. New Phytol. 133:25-43.

Heidstra, R., Geurts, R., Franssen, H., Spaink, H. P., van Kammen, A., and Bisseling, T. 1994. Root hair deformation activity of nodulation factors and their fate on Vicia sativa. Plant Physiol. 105:787-797.

Jefferson, R. A. 1987. Assaying chimeric genes in plants: The GUS gene fusion system. Plant Mol. Biol. Rep. 5:387-405.

Jefferson, R. A., Kavanagh, T. A., and Bevan, M. W. 1987. GUS fusions: $\beta$-glucuronidase as a sensitive and versatile gene fusion marker in higher plants. EMBO J. 6:3901-3907.

Kapp, D., Niehaus, K., Quandt, J., Müller, P., and Pühler, A. 1990. Cooperative action of Rhizobium meliloti nodulation and infection mutants during the process of forming mixed infected alfalfa nodules. Plant Cell 2:139-151.
Kijne, J. W. 1992. The Rhizobium infection process. Pages 349-398 in: Biological Nitrogen Fixation. G. Stacey, R. H. Burris, and H. J. Evans, eds. Chapman \& Hall, New York.

Klein, S., Hirsch, A. M., Smith, C. A., and Signer, E. R. 1988. Interaction of nod and exo Rhizobium meliloti in alfalfa nodulation. Mol. Plant-Microbe Interact. 1:94-100.

Leong, S. A., Williams, P. H., and Ditta, G. S. 1985. Analysis of the 5 regulatory region of the gene for $\delta$-aminolevulinic acid synthetase of Rhizobium meliloti. Nucleic Acids Res. 13:5965-5976.

Long, S. R. 1996. Rhizobium symbiosis: Nod factors in perspective. Plant Cell 8:1885-1898.

Mergaert, P., D’Haeze, W., Geelen, D., Promé, D., Van Montagu, M. Promé, J.-C., and Holsters, M. 1995. Biosynthesis of Azorhizobium caulinodans Nod factors. Study of the activity of the NodABCS proteins by expression of the genes in Escherichia coli. J. Biol. Chem. 270:29217-29223.

Mergaert, P., Ferro, M., D'Haeze, W., Van Montagu, M., Holsters, M., and Promé, J.-C. 1997a. Nod factors of Azorhizobium caulinodans strain ORS571 can be glycosylated with an arabinosyl group, a fucosyl group, or both. Mol. Plant-Microbe Interact. 10:683-687.

Mergaert, P., Van Montagu, M., and Holsters, M. 1997b. Molecular mechanisms of Nod factor diversity. Mol. Microbiol. 25:811-817.

Mergaert, P., Van Montagu, M., Promé, J.-C., and Holsters, M. 1993. Three unusual modifications, a D-arabinosyl, an $\mathrm{N}$-methyl, and a carbamoyl group, are present on the Nod factors of Azorhizobium caulinodans strain ORS571. Proc. Natl. Acad. Sci. USA 90:1551-1555.

Mylona, P., Pawlowski, K., and Bisseling, T. 1995. Symbiotic nitrogen fixation. Plant Cell 7:869-885.

O'Brien, T. P., Feder, N., and McCully, M. E. 1964. Polychromatic staining of plant cell walls by toluidine blue O. Protoplasma 59: 367-373.

O'Callaghan, K. J., Davey, M. R., and Cocking, E. 1997. Xylem colonization of the legume Sesbania rostrata by Azorhizobium caulinodans. Proc. R. Soc. Lond. B 264:1821-1826.

Relić, B., Perret, X., Estrada-García, M. T., Kopcinska, J., Golinowski, W., Krishnan, H. B., Pueppke, S. G., and Broughton, W. J. 1994. Nod factors of Rhizobium are a key to the legume door. Mol. Microbiol. 13:171-178.

Sambrook, J., Fritsch, E. F., and Maniatis, T. A. 1989. Molecular Cloning: A Laboratory Manual. 2nd ed. Cold Spring Harbor Laboratory, Cold Spring Harbor, NY.

Schlaman, H. R. M., Horvath, B., Vijgenboom, E., Okker, R. J. H., and Lugtenberg, B. J. J. 1991. Suppression of nodulation gene expression in bacteroids of Rhizobium leguminosarum biovar viciae. J. Bacteriol. 173:4277-4287.

Schultze, M., Kondorosi, É., Ratet, P., Buiré, M., and Kondorosi, Á. 1994. Cell and molecular biology of Rhizobium-plant interactions. Int. Rev. Cytol. 156:1-75.

Sharma, S. B., and Signer, E. R. 1990. Temporal and spatial regulation of the symbiotic genes of Rhizobium meliloti in planta revealed by transposon Tn5-gusA. Genes Dev. 4:344-356.

Spaink, H. P. 1996. Regulation of plant morphogenesis by lipo-chitin oligosaccharides. Crit. Rev. Plant Sci. 15:559-582.

Sprent, J. I., and de Faria, S. M. 1988. Mechanisms of infection of plants by nitrogen fixing organisms. Plant Soil 110:157-165.

Timmers, A. C. J., Auriac, M.-C., de Billy, F., and Truchet, G. 1998 Nod factor internalization and microtubular cytoskeleton changes occur concomitantly during nodule differentiation in alfalfa. Development 125:339-349.

Tsien, H. C., Dreyfus, B. L., and Schmidt, E. L. 1983. Initial stages in the morphogenesis of nitrogen-fixing stem nodules of Sesbania rostrata. J. Bacteriol. 156:888-897.

Van den Eede, G., Deblaere, R., Goethals, K., Van Montagu, M., and Holsters, M. 1992. Broad host range and promoter selection vectors for bacteria that interact with plants. Mol. Plant-Microbe Interact. 5: 228-234.

Van den Eede, G., Dreyfus, B., Goethals, K., Van Montagu, M., and Holsters, M. 1987. Identification and cloning of nodulation genes from the stem-nodulating bacterium ORS571. Mol. Gen. Genet. 206: 291-299.

van Workum, W. A. T., van Brussel, A. A. N., Tak, T., Wijffelman, C. A., and Kijne, J. W. 1995. Ethylene prevents nodulation of Vicia sativa ssp. nigra by exopolysaccharide-deficient mutants of Rhizobium leguminosarum bv. viciae. Mol. Plant-Microbe Interact. 8:278-285. 